\title{
Strategi Pembelajaran Penafsiran Ayat Al Qur'an Berbasis Maudhu'i Di Program Studi Ilmu Al Qur An Dan Tafsir Fakultas Ushuluddin IAIN Kota Kediri
}

\author{
Achmad Robi'ul Huda, ${ }^{1}$ Mahfudh \\ ${ }^{1}$ Pascasarjana Institut Agama Islam Tribakti Kediri, 2Institut Agama Islam Tribakti Kediri \\ 1robbiulhuda43@gmail.com,2ratukalinggajaya@gmail.com
}

\begin{abstract}
Abstrak
Penelitian ini dilakukan dalam tema strategi pembelajaran yang diterapkan pada Lembaga Pendidikan Islam, yang menerapkan metode pembelajaran menafsirkan ayat Al Qur'an. Fokus penelitian ini ada 2 yaitu (1) Strategi pembelajaran yang digunakan oleh Dosen Tafsir Al-qur'an pada Prodi IAT Fakultas Ushuludin di IAIN kota Kediri, (2) Penerapan metode maudhu'i dalam menafsirkan Ayat Al-qur'an pada Prodi IAT Fakultas Ushuludin di IAIN kota Kediri. Penelitian ini termasuk penelitian kualitatif deskriptif denga mengunakan wawancara, observasi, dan dokumentasi sebagai instrument pengalian data. Kemudian data yang didapat dari sumber-sumber tersebut dianalisis untuk mendapatkan keabsahan data, serta uraian interpretatif yang logis dan rasional berdasarkan data yang dikumpulkan. Hasil dari proses penelitian yang telah dilakukan, maka penulis menemukan temuan yang sesuai berdasarkan fokus penelitian diatas yang secara garis besarnya sebagai berikut (1) strategi pembelajaran yang diterapkan pada Prodi IAT Fakultas Ushuluddin IAIN Kediri merupakan termasuk strategi pembelajaran aktif (active learning), (2) penerapan metode tafsir maudhu'i yang dilakukan pada Prodi IAT Fakultas Ushuluddin IAIN Kediri menggunakan prosedurprosedur yang telah ditetapkan oleh imam-imam mufassir, yang kemudian dalam praktiknya menyesuaikan kebutuhan dari tema dan tujuan kajian penafsirannya.
\end{abstract}

Kata Kunci: Strategi Pembelajaran, Tafsir Al Qur 'an, Metode maudhu'i

\section{Pendahuluan}

Mempeiajari al-qur'an bagi setiap Muslim merupakan salah satu aktivitas terpenting, bahkan Rasul SAW. Menyatakan bahwa:

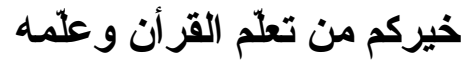

Terjemahnya: "Sebaik-baik kamu adalah siapa yang mempelajari al-Qur'an dan mengajarkannya" (HR. Bukhari).
Al Qur 'an adalah kitab suci yang memancar darinya aneka ilmu keislaman. Kitab suci ini juga dipercaya oleh umat Islam sebagai kitab petunjuk dalam segala sendi kehidupan yang hendaknya dipahami. Dalam konteks itulah lahir usaha untuk memahaminya secara mendalam. Hasilnya, Islam dikelnal mempunyai beberapa aneka disiplin ilmu dan pengetahuan. Siapa yang mengamati 
aneka disiplin ilmu keislaman, baik kebahasaan, keagamaan, maupun filsafat, kendati berbeda-beda dalam analisis, istilah, dan pemaparannya, namun kesemuanya menjadikan teksteks Al Qur 'an sebagai fokus pandangan dan titik tolak studinya. Karena itu pula semua ilmu keislaman saling bersinggungan dan berhubungan serta dukung mendukung dan saling memperkaya. ${ }^{1}$

Kenyataan ini menunjukkan bahwa semua kelompok umat Islam, apa pun alirannya, selalu merujuk kepada $\mathrm{Al}$ Qur'an untuk memperoleh petunjuk atau menguatkan pendapatnya. Bahkan, sementara non-Muslim menunjuk ayatayat dalam kitab suci umat Islam itu untuk meligitimasi idenya.

Atas dasar urgennya hal di atas, serta sejalan dengan kebutuhan ummat Islam untuk mengetahui seluruh segi kandungan Al Qur'an serta intensitas perhatian para ulama, maka tafsir $\mathrm{Al}$ Qur'an mengalami perkembangan yang pesat, baik dari aspek tafsir maupun metodologinya. Meskipun dalam hal ini, perkembangan metodologi tafsir tertinggal jauh dari kajian tentang tafsir itu sendiri.

Dalam dunia tafsir, cara yang digunakan oleh penafsir dalam mengungkapkan isi kandungan dan firman Allah beraneka ragam. Ada yang mengungkapkan penafsirannya sesuai dengan urutan-urutan ayat dalam mushaf Al Qur 'an, sehingga melahirkan pesan dan kandungan secara rinci dan luas. metode ini biasa dikenal dengan metode tahlili atau tajzi'i. Ada pula yang memilih topik tertentu kemudian mengumpulkan ayat-ayat yang berkaitan dengan topik tersebut di dalam Al Qur'an, baru kemudian dipaparkan kandungan dan pesan-pesan yang berkaitan dengan topik yang dipilihnya, atau dikenal dengan metode maudhu' $i^{2}$

Tafsir maudhu'i pertama kali lahir atas adanya inspirasi dari perkataan Ali bin Abi Thalib yang mengatakan istantiq Al Qur'an (ajaklah Al Qur'an berbicara atau biarkan ia menguraikan maksudnya). Pesan ini memberikan Inspirasi kepada penafsir untuk merujuk kepada Al Qur'an dalam rangka memahami kandungannya. Seorang penafsir harus menghimpun ayat-ayat $\mathrm{Al}$ Qur'an yang berkaitan dengan topik yang telah ditentukan sebelumnya. Setelah itu. Penafsir membahas dan menganalisis kandungan ayat-ayat tersebut sehingga menjadi satu kesatuan pesan Al Qur' an secara utuh. ${ }^{3}$

Metode ini kemudian menjadi metode yang banyak digunakan oleh para penafsir pada masa kini. Metode ini dianggap lebih mampu menjawab segala permasalahan dan menyuguhkan maksud Al-Qur'an secara tuntas. Jika ditilik sejarahnya, ulama yang pertama
${ }^{1}$ M. Quraish Shihab, Kaidah Tafsir : Syarat, Ketentuan, Dan Aturan Yang Patut Anda Ketahui
2 M. Quraish Shihab, Wawasan Al-Qur'an (Bandung: Mizan, 1998), h. Xi-Xii

3 M. Quraish Shihab, Membumikan AlQur'an (Bandung: Mizan, 2009), h. 131-132. 
kali menggunakan metode ini adalah Mahmud Syaltut dengan karyanya Tafsir Al Qur'an Al Karim yang diterbitkan pada bulan Januari 1960. Syaltut menafsirkan Al Qur'an bukan ayat demi ayat, tetapi membahas surat demi surat atau bagian-bagian dalam surat dengan menjelaskan tujuan utama serta petunjuk-petunjuk yang dirangkum dari sekumpulan ayat tersebut. Meskipun ide tentang kesatuan dan isi petunjuk surat demi surat pernah disampaikan oleh AlSyatibi, namun penerapannya dalam suatu kitab tafsir baru dilakukan oleh Mahmud Syaltut. ${ }^{4}$

Secara khusus, kajian Al Qur'an yang dilakukan ummat Islam lebih banyak dilakukan oleh lembaga-lembaga pendidikan Islam yang bertaraf Perguruan Tinggi atau Pondok Pesantren. Oleh karena hal inilah penulis fokuskan menganalisis bagaimana proses penerapan serta faktor-faktor penunjang dan hambatan metode maudhu'i pada program study Ilmu Al Qur'an dan Tafsir Fakultas Ushuluddin Institut Agama Islam Negeri (IAIN) Kediri. Temuan awal,

Dari paparan konteks penelitian diatas, maka penulis dapat merumuskan fokus penelitian sebagai berikut:

1. Strategi pembelajaran yang digunakan oleh Dosen Tafsir Al Qur'an pada Prodi Tafsir Qur'an Fakultas Ushuluddin di Institut Agama Islam Negeri Kota Kediri.
2. Penerapan metode maudhu'i dalam menafsirkan Ayat Al-qur'an pada Prodi Tafsir Qur'an Fakultass Ushuluddin di Institut Agama Islam Negeri Kota Kediri.

\section{Metode}

Rancangan dalam penelitian ini menggunakan pendekatan kualitatif, yaitu prosedur penelitian yang menghasilkan data deskriptif berupa kata atau tulisan dari sumber data yang diamati. Metode deskriptif adalah metode penelitian tentang dunia empiris yang terjadi pada masa sekarang. Tujuannya untuk membuat deskriptif, gambaran atau lukisan secara sitematis, faktual dan akurat mengenai fakta-fakta, sifat-sifat dan hubungan antar fenomena yang diteliti. ${ }^{5}$

Lebih jauh, pendekatan kualitatif digunakan dalam penelitian ini karena metode ini menyajikan secara langsung hakikat hubungan antara penelitian dan responde. Disamping itu, penelitian kualitatif lebih peka dan lebih dapat menyesuaikan diri dari berbagai bentuk pengaruh dan pola-pola nilai yang dihadapi.

Sedakan seting penelitian di Fakultas Ushuluddin Program Study Ilmu Al-Qur'an dan Tafsir Institut Agama Islam Negeri, beralamatkan di Jl. Sunan Ampel, No.7 Ngronggo Kota Kediri Jawa Timur. 


\section{Pembahasan}

\section{Strategi Pembelajaran}

Dari data yang ditemukan oleh peneliti melalui observasi di lapangan, dalam proses kegiatan pembelajaran di Prodi Ilmu Al Qur'an dan Tafsir Fakultas Ushuluddin di IAIN Kota Kediri, sesuai dengan fokus penelitian yang penulis pilih, mendapatkan beberapa temuan sebagai berikut:

\section{Penerepan Strategi Active Learning}

Dalam proses perkuliahan yang dilakukan pada Program Studi Ilmu Al Qur'an dan Tafsir, para dosen menggunakan strategi pembelajaran active learning. Menurut penuturan Dr. $\mathrm{H}$. Moh. Akib, M.Ag selaku ketua Prodi IAT Fakultas Ushuluddin IAIN Kota Kediri, beliau menuturkan sebagai berikut:

"Proses pembelajaran yang dilakukan oleh para Dosen lebih menitik beratkan untuk para mahasiswa agar menjadi lebih aktif dan mandiri. Aktif dalam mencari referensi, berdiskusi, dan dalam menerapkan sebuah teori/metode suatu materi perkuliahan.." 6

Menambahkan dari keterangan di atas, yang terkait dengan langkahlangkah strategi pembelajarannya, bapak H. Zainal Muttaqin M.A., selaku sekretaris Prodi IAT, menyampaikan bahwa;

"Langkah-langkah pembelajaran yang ada pada Fakultas Ushuluddin khususnya Prodi IAT adalah dengan mengadakan perkuliahan seperti pada umunya, mengawali dengan pemaparan pengantar dari materi matakuliah dan kemudian menyampaikan poin-poin atau teori-teori yang yang ada 2 (dua) atau 3 (tiga) pertemuan awal, kemudian memberikan tugas kepada mahasiswa sesuai dengan tema-tema yang sudah ditentukan oleh dosen yang sesuai sengan materi ajarnya, setelah itu mahasiswa melakukan presentasi dan diskusi, kemudian pada akhir masa Semester diadakan Ujian Akhir Semester sebagai salah satu tolok ukur penilaian dalam kefahaman mahasiswa terhapat materi yang telah diajarkan."7

Dalam perihal penugasan yang diberikan oleh dosen, Prof. H. Fauzan Saleh, M.A, Ph.D selaku guru besar Fakultas Ushuluddin dan Dakwah IAIN

Kota Kediri, menyampaikan demikian ; "penugasan yang dilakukan meliputi tugas kelompok yang telah di sepakati dalam forum perkuliahan, yang kemudian diberikan jangka waktu antara 2 (dua) minggu untuk menyelesaikan tugas yang telah diberikan. Yang kemudian dalam penyampaian hasil penugasan tersebut akan dillihat juga referensi yang digunakan oleh mahasiswa apakah sudah mencakup dan mencukupi untuk tema yang sedang disampaikan serta melihat kemampuan dan 
juga kefahaman mahasiswa terhadap materi tersebut." 8

2. Penggunaan media pembelajaran

Adapun untuk media pembelajaran yang digunakan, sesuai dengan yang disampaikan oleh bapak Dr. Akib antara lain adalah proyektor, perpus digital, maktabah syamilah serta kitab-kitab tafsir yang sesuai dengan teori/metode yang sedang digunakan, dan kegiatan tersebut dilakukan pada ruang Laboratorium Prodi IAT. Berdasarkan temuan observasi penulis pada ruang Laboratorium yang digunakan, ruangan ini berukuran $4 \times 8$ meter persegi, yang berisikan satu perangkat komputer yang berada di meja pengajar, satu buah proyektor, whiteboard, beberapa buku/kitab sebagai referensi langsung dan beberapa kursi untuk mahasiswa.

Dan dari beberapa hasil temuan observasi penulis, dari kesemua yang disampaikan diatas memang ada dan cukup memadai untuk digunakan sebagai media pembelajaran yang diterapkan.

3. Tenaga pengajar yang dimiliki

Selain dari penerapan strategi yang tepat, pengajar atau dosen yang mengampu matakuliah juga memiliki peranan yang sangat penting, untuk menunjang tersampaikannya materi pembelajaran yang tepat serta menjadi fasilitator yang mampu mengembangkan potensi dan pemahaman mahasiswa.
Dalam observasi data dan narasumber yang penulis dapatkan, hal ini sudah terbilang sangat mencukupi. Sebagaimana yang disampaikan oleh bapak Dr. Akib bahwa dosen-dosen yang mengajar pada Prodi IAT sebagian besar sudah memiliki SK sebagai pengajar IAT, dan bahkan salah satu dari dosen pengajar pada Prodi IAT adalah guru besar Fakultas Ushuluddin IAIN Kediri. Bapak Muttaqin menambahkan bahwa dosen pengajar yang bertugas pada Prodi IAT khususnya yang mengampu mata kuliah metode tafsir maudhu'i mengajar sesuai dengan bidang penguasaan yang dimilikinya. Contohnya, Prof. H. Fauzan Saleh, M.A,Ph.D sebagai dosen mata kuliah tafsir metode maudhu'i dengan fokus pada bidang akhlaq/etika, Dr. H. Ahmad Subakir, M.Ag sebagai dosen mata kuliah tafsir metode maudhu'i dengan fokus pada bidang akidah, Dr, A. Halil Thahir, M.HI sebagai dosen matakuliah Tafsir Metode Maudhu'I dengan fokus pada bidang ahkam ibadah.

Adapun perihal lain seperti halnya hambatan dalam penerapan strategi pembelajaran pada Prodi IAT Fakultas Ushuluddin IAIN Kediri, tidak ada hambatan yang cukup berarti. Hambatan yang terjadi ada pada penerapan Metode pembelajaran yang akan di paparkan pada sub bab selanjutnya.

8 Observasi wawancara dengan bapak Prof. H. Fauzan Saleh, M.A, Ph.D, pada tanggal 1 Agustus 2019 


\section{Penerapan Metode Maudhu'I}

Sebagaimana hasil observasi dan pemaparan strategi pembelajaran yang di terapkan oleh para Dosen diatas, maka selanjutnya dalam penerapan Metode Maudhu'I yang dilaksanakan di Program Studi Ilmu Al-Qur'an dan Tafsir Fakultas Ushuluddin IAIN Kota Kediri, hasil observasi yang penulis dapatkan ada beberapa poin, yaitu ;

a) Model metode Tafsir Maudhu'i yang digunakan

Model atau langkah-langkah dalam menerapkan metode tafsir Maudhu'I pada Prodi IAT Fakultas Ushuluddin IAIN Kediri, merujuk kepada beberapa metode yang dilakukan oleh beberapa Mufassir terdahulu, sebagaimana yang disampaikan oleh Bapak Akib "penerapan metode maudhu'I disini penerapannya tidak hanya terpaku pada satu epistemologi satu metode tafsir mudhu'I saja, tetapi menggunakan beberapa epistemologi tafsir maudhu'i seperti halnya tafsir metode maudhu'inya imam al-Farmawi, imam ibnu Taimiyah, imam al-Kumy dll." 9

Perbedaan penggunaan epistemologi atau konsep metode tafsir maudhu'liini, dipengaruhi atas dasar objek dan kontekstualisasi dari ayat atau tema yang akan di rumuskan, sehingga hasil yang dicapai nnti dapat merepresentasikan apa yang sedang terjadi pada dewasa sekarang atau aktualisasi makna al-Qur'an. Hal ini juga bertujuan agar mahasiswa memiliki banyak bekal ketika nantinya mereka sudah terjun dalam dunia penafsiran alQur'an. ${ }^{10}$

b) Penerapan Metode Tafsir Maudhu'i

Dalam pelaksanaan pembelajaran matakuliah metode penafsiran Maudhu'I, mahasiswa dituntut untuk dapat mengklasifikasi ayat-ayat berdasarkan tema tertentu serta mengetahui maksud dan sebab turunnya ayat tersebut. Hal ini pada umumnya diterapkan juga pada metode-metode Tafsir lainnya, karena pada dasarnya hal tersebut adalah dasar awal untuk dapat menafsiri suatu ayat atau surat pada $\mathrm{Al}$ Qur'an. Hanya saja pada setiap metode memiliki konsep dan coraknya masingmasing, namun beberapa memiliki persamaan dan perbedaannya.

Dalam praktik penerapan Metode Tafsir Maudhu'I yang dilakukan Prodi IAT Fakultas Ushuluddin IAIN Kediri, sebagaimana yang disampaikan oleh Bapak Dr. Akib;

"Praktikum yang dilakukan oleh mahasiswa adalah dengan cara mahasiswa langsung membedah isi dan makna suatu al-Qur'an dengan tema yang telah ditentukan, kemudian mahasiswa mencari ayat-ayat yang berbicara terkait tema tersebut atau di kenal dengan istilah klasifikasi ayat, yang kemudian dicari arti, maksud dan sebab turunnya ayat tersebut yang telah diklasifikasi, kemudian langkah selanjutnya ayat-ayat tersebut disusun sesuai dengan hasil temuan yang ada, dan bila diperlukan maka akan 
diberi tambahan referensi lain seperti keterangan dari kitabkitab atau karya ulama yang terdahulu dan terkait dengan tema yang sedang dibahas." 11

Prof. Fauzan menambahkan dalam perihal praktiknya di lapangan sebagai berikut;

"semisal ketika mahasiswa ditugaskan untuk mengulas tema tentang kasih sayang atau cinta, maka mahasiswa harus mencari ayat-ayat atau mengklasifikasikan ayat-ayat yang menerangkan terkait kasih sayang atau cinta (حُبُّ), setelah itu mahasiswa mengklasifikan lagi mana yang maknanya khusus dan umum dalam kata atau ayat tersebut. Kemudian mencari sebab turunnya ayat tersebut dan memastikan apakah ayat tersebut berupa ayat makiyah atau madaniyah, karena dalam ayat makiyah dan madaniyah memiliki subjek hukum yang berbeda, dalam makiyah subjek hukumnya adalah kelompok yang minoritas sedangkan dalam madaniyah subjek hukumnya adalah kelompok mayoritas. Kemudian baru menyusun atau merangkai ayat-ayat tersebut menyesuaikan maksud dan tujuan tema yang telah ditentukan."12

\section{Faktor pendukung dan Penghambat}

Sebagaimana pada umumnya penerapan suatu metode pembelajaran, pastilah memiliki beberapa faktor yang menjadi pendukung dan kendala dalam pelaksanaannya. Berikut hasil observasi yang penulis dapatkan perihal beberapa hal yang menjadi faktor pendukung dan kendala dalam penerapan metode tafsir maudhu'i;

\section{Faktor pendukung}

Melihat dari penerapan metode yang digunakan serta objek pembelajaran yang digunakan adalah termasuk fan keilmuan gramatikal Bahasa Arab, maka yang menjadi faktor pendukung utamanya adalah, pertama sudah banyaknya terjemah-terjemah kitab/buku yang menjadi referensi dalam Metode Tafsir Maudhu'i, dimana pada mulanya metode ini berkembang pada masa imam-imam berkebangsaan Arab atau Timur Tengah, yang pada dasarnya mereka menggunakan redaksi berbahasa Arab. Kedua, faktor pendukung selanjutnya adalah cukup banyak aplikasi-aplikasi digital yang memang dipergunakan untuk membantu kajian-kajian semacam ini. ${ }^{13}$

2. Faktor kendala

Sebagaimana penjelasan sebelumnya terkait referensi yang digunakan dalam penerapan metode ini, berdasarkan observasi yang penulis dapatkan, kendala yang terjadi disini terletak pada mahasiswa yang tidak memiliki basic/dasar-dasar ilmu yang menunjang dalam memahami referensi yang digunakan dalam kajian Metode Tafsir Maudhu'i. Ilmu-ilmu ini dikenal 
dengan ilmu gramatikal Arab yang memiliki beberapa spesifikasi keilmuan tertentu, seperti halnya ilmu Nahwu, Shorof, Mantiq, Balaghoh dll. Kendala yang demikian ini tidak cukup jika hanya dibantu dengan menggunakan kamus atau terjemah saja, karena terkadang yang ada di dalam terjemah hanya di ambil pengertian-pengertian singkat dari kalimat asli yang berbahasa arab. Karena justru terkadang di dalam kata atau kalimat asli yang terbuang ini, terdapat maksud arti yang berperan penting untuk merumuskan maksud arti pada ayat-ayat yang sedang di kaji. ${ }^{14}$

\section{Analisis Temuan}

Pada setiap lembaga penididikan pastilah bertujuan menghasilkan output yang unggul dan berkompeten pada bidangnya, sebagaimana cita-cita dan target yang terdapat pada visi dan misi yang dimiliki, sehingga dituntut untuk dapat memaksimalkan potensi dan kemampuan yang ada. Salah satu upaya yang pasti dilakukan adalah dengan menjalankan pengelolaan lembaga yang sesuai aturan dan prosedur yang ada, serta menerapkan strategi dan metode pembelajaran yang tepat dan maksimal.

\section{Pembahasan strategi pembelajaran}

Merujuk kepada paragraf di atas, maka berdasarkan data-data yang penulis dapatkan, pembahasan yang pertama adalah dalam perihal strategi pembelajaran yang diterapkan di Prodi IAT Fakultas Ushuluddin IAIN Kediri sudah memaksimalkan kemampuan mahasiswa, yaitu dengan menerapkan strategi pembelajaran aktif. Dengan strategi pembelajaran tersebut membuat mahasiswa ikut berperan aktif dalam kegiatan belajar sehingga menciptakan suasana belajar yang kolaboratif, suasana yang bebas dan kreatif, menyenangkan, interaktif partisipatif, mendorong keterlibatan fisik dan mental, dan berorientasi problem solving.

Suasana pembelajaran aktif seperti di atas memerlukan penerapan strategistrategi pembelajaran yang dapat mendorong keterlibatan aktif mahasiswa dalam kegiatan pembelajaran, agar tujuan pembelajaran dapat terlaksana secara efektif. Beberapa strategi yang diterapkan disini berdasarkan data yang penulis dapatkan, yang sesuai dan termasuk dengan strategi-strategi pembelajaran aktif antara lain;

a. strategi group resume, dengan strategi ini mahasiswa diarahkan untuk melakukan kegiatan bertukar pendapat dan pengalaman, meringkas atau mengambil pokok-pokok pikiran, menyimpulkan secara bersama-sama intisari pelajaran. Dalam prakteknya adalah mahasiswa melakukan diskusi atas tugas dari masing-masing kelompok yang terdiri dari 7-10 mahasiswa, kemudian membuat rangkuman dari hasil diskusi tersebut.

b. strategi point counter point, dengan strategi ini mahasiswa diarahkan untuk melakukan kegiatan mengungkapkan gagasan, mengajukan kritik, 
mempertahankan pendapat, mengatur sendiri mekanisme diskusi, mengendalikan alur dialog. Dalam prakteknya adalah mahasiswa melakukan diskusi dengan tema tertentu yang sudah ditentukan oleh dosen, salah satu mahasiswa ditunjuk untuk menjadi moderator untuk mengarahkan alur diskusi.

c. strategi reading guide, dengan strategi ini mahasiswa diarahkan untuk melakukan kegiatan membaca dan memahami bahan ajar, mengambil pokok-pokok pikiran. Dalam prakteknya adalah mahasiswa diberikan tugas untuk mengkaji metode tafsir atau corak penafsiran dari beberapa tokoh mufassir, kemudian outputnya mahasiswa menyetorkan rangkuman dari poinpoin materi tersebut dalam bentuk tulisan tangan.

d. strategi modeling the way, dengan strategi ini mahasiswa diarahkan untuk melakukan kegiatan membaca, memahami isi bacaan, mendiskusikan, mendemonstrasikannya, bertanya dan menjawab, memberikan feedback. Dalam prakteknya adalah mahasiswa di jadikan beberapa kelompok kecil yang terdiri dari 7-10 mahasiswa, kemudian masingmasing kelompok diberikan satu materi ajar, yaitu sebuah metode penafsiran, setiap mahasiswa diharuskan membaca dan memahami masing-masing metode tersebut yang kemudian setiap kelompok melakukan diskusi terkait pemaha- man metode tersebut yaitu dengan melakukan presentasi oleh salah satu dari masing-masing kelompok, kemudian yang lainnya saling memberikan feedback atas pemahaman masing-masing mahasiswa terhadap metode tersebut.

e. strategi physical self assessment, dengan strategi ini mahasiswa diarahkan untuk melakukan kegiatan menyatakan sikap atau pendiriannya, mengemukakan argumen-argumen atas sikapnya, menjawab pertanyaanpertanyaan yang diajukan. Dalam prakteknya adalah mahasiswa melakukan presentasi atas tugasnya yang kemudia mahasiswa lainnya memberikan pandangannya masingmasing materi yang dipresentasikan, serta memberikan pertanyaan kepada presentator.

f. strategi problem solving, dengan strategi ini mahasiswa diarahkan untuk melakukan kegiatan diskusi untuk pemecahan masalah, membuat kesimpulan, melakukan presentasi, memberikan feedback. Dalam prakteknya adalah mahasiswa diberikan tugas untuk mencari solusi atas sebuah persoalan yang sedang terjadi, berdasarkan metode-metode yang telah dipelajari, dengan melakukan pendalaman kasus, mencari metode yang tepat untuk mencari solusi menyelsaikan kasus tersebut, kemudian melakukan diskusi dan saling memberikan hasil kajiannya masing-masing. 
g. strategi kolaborasi, dengan strategi ini mahasiswa diarahkan untuk melakukan kegiatan melakukan kerjasama secara kooperatif, memanfaatkan berbagai media dan sumber belajar untuk mancapai satu tujuan. Dalam prakteknya adalah mahasiswa dijadikan beberapa kelompok yang terdiri atas 7-10 mahasiswa, kemudian masingmasing kelompok diberikan tugas untuk mencari kasus-kasus terkini yang terjadi, kemudian masingmasing mahasiswa dari kelompoknya masing-masing melakukan kajian dengan membagi tugas dan bekerjasama untuk menyelasaikan atau meberikan solusi atas kasus tersebut.

Pemaparan hasil di atas menunjukkan bahwa para dosen IAT telah melakukan upaya-upaya untuk menerapkan berbagai strategi pembelajaran aktif (active learning), bertujuan agar proses pembelajaran dapat berjalan dengan maksimal serta efektif.

2. Pembahasan metode maudhu'i

Pembahasan yang kedua, perihal metode pembelajaran Tafsir al-Qur'an dengan Metode Tafsir Maudhu'i, berdasarkan observasi yang penulis lakukan di lapangan ditambah dengan keterangan dari narasumber, penerapan metode ini secara garis besar, dalam segi teori dan konsep-konsep metode pembelajaran Tafsir Maudhu'i sudah sesuai dengan prosedur-prosedur yang ada dan telah di sepakati oleh para ulama mufassir, yaitu menyesuaikan kebutuhan dan latar belakang permasahalan dari tema yang telah ditentukan. Sehingga maksud dan tujuan penafsiran yang dilakukan, menjadi lebih tepat dalam proses pengkajian tema ayat, untuk menyajikan produk penafsiran yang mampu memenuhi kebutuhan tema atau zaman.

3. Temuan dalam segi Metodologis Maudhu'I.

Temuan mendasar yang ditemukan peneliti adalah, pengaplikasian teori berdasarkan tema/problematika yang akan dibahas. Antara lain: (1) Teori Imam Ibnu Taimiyah diaplikasikan dalam bidang politik, (2) Teori Imam Syaltut digunakan dalam bidang Ilmu Pengetahuan, (3) Teori Imam Suyuti digunakan dalam bidang Fiqih atau 'Ubudiyah, dan beberapa Imam Mufassir lain yang memiliki Karakteristik dan keahlian masing-masing.

Selain pembahasan dalam segi teori dan konsep-konsep penafsiran, ada pembahsan dalam segi lain yang menjadi kekurangan pada penerapan metode Tafsir Maudhu'i ini. Pembahasan tersebut adalah pada segi sumber daya manusia yang menjadi objek penerapan metode tafsir maudhu'I ini, yaitu mahasiswa. Pada segi ini, dalam pelaksanaannya bahkan menjadi kendala pada semua metode pembelajaran yang ada di Prodi IAT Fakultas Ushuluddin IAIN Kediri. Kendala yang terjadi adalah belum maksimalnya kompetensi dari sumber daya manusia mahasiswanya, hal ini terjadi atas dasar beberapa sebab, yaitu:

1. Kurang ketatnya proses seleksi yang dilakukan dalam penerimaan 
mahasiswa baru, dikarenakan yang akan masuk dan mengikuti seleksi ini adalah para calon mahasiswa yang memililki banyak latar belakang pendidikan yang berbeda-beda, dan yang menjadi permasalahan utama adalah para calon mahasiswa yang tidak memiliki latar belakang pendidikan kepesantrenan atau agama. Dimana sesuai dengan yang telah dijelaskan sebelumnya, bahwa bekal dasar seseorang untuk bisa dan layak melakukan kajian penafsiran alQur'an adalah mengetahui dan memahami fan keilmuan gramatikal arab, diantaranya ilmu nahwu, shorof, kalam, balaghah dan lain sebagainya.

2. Kurangnya pendampingan kepada mahasiswa yang belum memiliki kemampusan dasar untuk mengkaji kitab atau referensi pokok dari kajian Tafsir yang menjadi kajian pokoknya. Dimana hal tersebut sebagaimana yang telah dijelaskan sebelumnya, merupakan modal dasar seseorang dalam melakukan kajian penafsiran al-Qur'an.

Demikianlah beberapa temuan yang penulis dapatkan dari hasil observasi dan keterangan narasumber di lapangan, temuan yang didapatkan adalah adanya beberapa kelebihan dan kekurangan dalam penerapan strategi pembelajaran serta metode pembelajarannya.

\section{Kesimpulan}

Dari penelitian yang penulis lakukan dapat disimpulkansebagai berikut;
1. Dalam penerapan strategi pembelajaran oleh para dosen di Prodi IAT Fakultas Ushuluddin IAIN Kediri, merupakan strategi pembelajara aktif (Active Learning) yang menciptakan suasana belajar yang kolaboratif, suasana yang bebas dan kreatif, menyenangkan, interaktif-partisipatif, mendorong keterlibatan fisik dan mental, dan berorientasi problem solving.

2. Dalam segi penerapan Metode Tafsir Maudhu'i, menurut hemat penulis masih sangat relevan dalam menyelesaikan problematika pada dewasa sekarang, yaitu dengan cara menyesuaikan epistemologi dan konsep-konsep tafsir maudhu'i yang ada dengan tema dan kontekstualisasi maksud 


\section{Daftar Pustaka}

Dadang Khamad, Sosiologi Agama Bandung: Pt. Remaja Rosda Karya, 2009

Shihab, M. Quraish. Kaidah Tafsir : Syarat, Ketentuan, Dan Aturan Yang Patut Anda Ketahui Dalam Memahami AyatAyat Al-Qur'an, Tangerang: Lentera Hati, 2013

Membumikan Al-Qur'an Bandung: Mizan, 2009

Wawasan Al-Qur'an Bandung: Mizan, 1998 